UDC 577.112.7:616

\title{
EXPRESSION OF ANTI-ANGIOGENIC GENES IN SUBCUTANEOUS ADIPOSE TISSUE OF THE OBESE INDIVIDUALS WITH PRE-DIABETES AND TYPE 2 DIABETES
}

\author{
O. O. Ratushna ${ }^{1}$, D. O. Minchenko ${ }^{1,2}$, \\ S. V. Danilovskyi ${ }^{1}$, I. Klimes $^{3}$, O. H. Minchenko ${ }^{1}$ \\ ${ }^{1}$ Palladin Institute of Biochemistry, NAS of Ukraine, 9, Leontovych St., Kyiv 01601, Ukraine \\ ${ }^{2}$ O.O. Bohomoletz National Medical University, 13, Shevchenko Boulvd., Kyiv 01601, Ukraine \\ 3 Institute of Experimental Endocrinology, Slovak Academy of Sciences \\ Bratislava 83306, Slovak Republic \\ e-mail: ominchenko@yahoo.com
}

Accumulating evidence raises the hypothesis that dysregulation of different intrinsic mechanisms which control most metabolic processes are involved in the development of obesity, metabolic syndrome and type 2 diabetes mellitus, the most profound public health problems. Angiogenesis is an important component of different proliferative processes, in particular, fat tissue growth. Moreover, dysregulation of molecular components of the angiogenesis system can contributes to the development of diabetic complications. We have studied the expression levels of genes related to regulation of angiogenesis (TIMP1, TIMP2, TIMP3, TIMP4, THBS1, THBS2, THBS3, ADAMTS5, LUM, $D C N$, IL6 and ZEB1) in subcutaneous adipose tissue of obese individuals as well as obese patients with impaired glucose tolerance (prediabetic) and type 2 diabetes using real-time quantitative PCR. We have shown that the expression level of most of these genes with anti-angiogenic properties significantly increases in subcutaneous adipose tissue of obese individuals versus lean patients, being more intense for TIMP1, TIMP2, THBS2 and LUM genes. Increased expression level of TIMP1, TIMP2, TIMP3, ADAMTS5 as well as THBS1 and THBS2 in adipose tissue was found in obese patients with impaired glucose tolerance. At the same time, expression of genes which encode for TIMP1 and TIMP2 strongly decreased in adipose tissue of obese individuals with type 2 diabetes versus subjects with glucose intolerance. Results of this study provide strong evidence that expression of genes mostly related to suppression of angiogenesis is dysregulated in adipose tissue of obese individuals as well as in obese patients with glucose intolerance and type 2 diabetes. It is possible that these changes in the expression of TIMP and THBS genes in adipose tissue in obesity as well as in obese individuals with impaired glucose tolerance and type 2 diabetes can contribute to fat tissue storage, insulin resistance and the development of diabetic complications.

Keywords: mRNA expression, TIMP1, TIMP2, TIMP3, THBS1, THBS2, ADAMTS5, LUM, DCN, ZEB1, human adipose tissue, obesity. 


\section{INTRODUCTION}

Accumulating evidence raises the hypothesis that dysregulation of different intrinsic mechanisms which control most metabolic processes are involved in the development of obesity, metabolic syndrome and type 2 diabetes mellitus, the most profound public health problems. Angiogenesis is an important component of different proliferative processes, in particular, fat tissue growth. Moreover, dysregulation of molecular components of the angiogenesis system can contributes to the development of diabetic complications. Recently, a number of studies have provided support for a link between the altered sleep/wake patterns, namely the circadian clock, and obesity [1-3]. Biological rhythms are an integral component of essentially all aspects of life and regulate many physiological functions, including metabolism, insulin sensitivity and cellular proliferation and its dysregulation involved in the development of obesity, metabolic syndrome as well as type 2 diabetes mellitus [4-6]. Moreover, obesity is a well-known risk factor for the development of insulin resistance and secondary complications such as type 2 diabetes.

Adipose tissue growth is tightly associated with cell proliferation processes and angiogenesis regulated by different factors and are tightly interconnected; however, the vascular endothelial growth factor (VEGF) is a key factor which activity depends upon many factors. Special interest represents matrix proteins with pleiotropic roles which are linked to human obesity and diabetes complications because to reveal anti-angiogenic properties and appear to regulate cell growth and apoptosis [7-11].

Thrombospondin 1 (THBS1 or TSP1) is an adhesive glycoprotein that mediates cell-to-cell interactions, has anti-angiogenic properties and inhibits of cell growth [7]. It was shown that decorin (DCN) which antagonizes the angiogenic network induces the expression of thrombospondin-1 and tissue inhibitor of matrix metalloproteinase 3 (TIMP metallopeptidase inhibitor 3; TIMP3), but inhibits vascular endothelial growth factor A (VEGFA) [8]. It has recently been shown that endothelial nitric oxide synthase controls the expression of the angiogenesis inhibitor thrombospondin 2 and ADAM metallopeptidase with thrombospondin type 1 motif, 5 (ADAMTS5) [9, 10].

There are four genes encoding tissue inhibitor of matrix metalloproteinase (TIMP1, TIMP2, TIMP3 and TIMP4) with different regulatory properties. TIMP1 is able to promote cell proliferation in a wide range of cell types, and may also have an anti-apoptotic function. At the same time, TIMP1 is a potent inhibitor of tumor growth and angiogenesis and is involved in cell adhesion and migration. It also controls adipogenesis in obesity both in mice and in humans as a negative regulator [11]. TIMP2 thought to be a metastasis suppressor and has a unique role among TIMP family members in its ability to directly suppress the proliferation of endothelial cells.

Moreover, Dews et al. [12] have shown that enhanced neovascularization correlated with downregulation of anti-angiogenic thrombospondin-1 and related proteins, such as connective tissue growth factor (CTGF), besides that both THBS1 and CTGF are predicted targets for repression by the miR-17-92 microRNA. Moreover, VEGFA binds connective tissue growth factor and that its angiogenic activity is inhibited in the VEGFA-CTGF complex form; however, stability of this complex as well as the angiogenic activity of VEGF depends from matrix metalloproteinases and its inhibitors [13].

It has recently been shown that transcription factor retinoid-related orphan receptor gamma (RORG) is a negative regulator of adipocyte differentiation and modulates insulin sensitivity in obesity through expression of metalloproteinase 3 and its inhibitors [14].

ISSN 1996-4536 • Біологічні Студії / Studia Biologica • 2012 • Том 6/№2 • С. 17-32 
The ADAM metallopeptidase with thrombospondin type 1 motif, 5 (ADAMTS5) regulates the fibroblast-myofibroblast transition by maintain optimal versican content [15]. Lumican (LUM), decorin (DCN), interleukin-6 (IL6) and interleukin-1b (IL1B) have also shown anti-angiogenic properties. Their expression is controlled by zinc finger E-boxbinding homeobox 1 transcription factor (ZEB1), also known as TCF8 [7, 16-19]. DCN is a small cellular or pericellular matrix proteoglycan and plays a role in matrix assembly. It is important to note that nuclear localized decorin is capable of suppressing growth as well as migration and invasion of various tumor cell lines [16, 17]. Moreover, decorin antagonizes IGF receptor I function by attenuating downstream signaling. LUM may regulate growth and cell migration as well as angiogenesis. There is data that IL1B stimulates lumican expression which can modulate TGFB2 activity [18]. Transcription factor ZEB1 likely plays a role in transcriptional repression many genes, including interleukins [19].

Recently was shown that the endothelial dysfunction in diabetes mellitus resulting in vascular endothelial growth factor resistance despite the presence of functionally active VEGF receptor 1 [20].

The endoplasmic reticulum stress is recognized as an important determinant of type 2 diabetes and contributes to the expression profile of many regulatory genes resulting in peripheral insulin resistance and diabetic complications [21-24]; however, a detailed molecular mechanism of the development of obesity and type 2 diabetes mellitus in some representatives of obese individuals is not yet clear and remains to be determined.

The main goal of this work is to study the role of the expression of genes related to the regulation of angiogenesis (TIMP1, TIMP2, TIMP3, TIMP4, THBS2, THBS3, ADAMTS5, LUM, DCN, IL6 and ZEB1) in subcutaneous adipose tissue of obese individuals as well as obese patients with impaired glucose tolerance and type 2 diabetes for evaluation of its significance to the development of human obesity, initial stages of metabolic disease (prediabetes) and type 2 diabetes mellitus.

\section{MATERIALS AND METHODS}

Patients' characteristics. The 24 male subjects participate in the study. They were divided into four groups ( 6 men in each group): lean individuals and patients with obesity, prediabetes and type 2 diabetes mellitus.

Subjects studied were recruited from the patients' cohort within the LipidomicNet Project at Institute of Experimental Endocrinology Slovak Academy of Sciences. All participants gave written informed consent and the studies were approved by the local research bioethics committees of Institute of Experimental Endocrinology.

Clinical characteristics of the study participants are shown in Table 1. The lean (control) participants were individuals with mean age $45 \pm 8$ years and mean body mass index (BMI) $23 \pm 1.4 \mathrm{~kg} / \mathrm{m}^{2}$. The obese participants as well as the patients with prediabetes and type 2 diabetes were individuals with mean age $(45 \pm 8 ; 44 \pm 7$ and $48 \pm 8$ years, correspondingly) and mean BMI (32 $\pm 1.4 ; 34 \pm 1.4$ and $33 \pm 2.4 \mathrm{~kg} / \mathrm{m}^{2}$, correspondingly). Thus, BMI in these groups of patients was significantly higher as compared to lean individuals (Table 1 ).

Prediabetes was classified according to the impaired glucose tolerance. Type 2 diabetes was classified according to the WHO (1999) criteria as fasting plasma glucose $>7.0 \mathrm{mmol} / \mathrm{l}$ or $2 \mathrm{~h}$ glucose $>11.1 \mathrm{mmol} / \mathrm{l}$ during an oral glucose tolerance test (OGTT). For this study, some individuals with type 2 diabetes were excluded from the analysis of quantitative traits. 
Table 1. Characteristics of the study participants

Таблиця 1. Характеристика учасників дослідження

\begin{tabular}{l|c|c|c|c}
\hline \multicolumn{1}{c|}{ Variable } & Lean, NGT & Obese, NGT & Obese, IGT & Obese, diabetes \\
\hline Age at visit (years) $(n)$ & $45 \pm 8.3(6)$ & $45 \pm 7.4(6)$ & $44 \pm 7.8(6)$ & $48 \pm 7.1(6)$ \\
\hline Body mass index $(\mathrm{BMI})\left(\mathrm{kg} / \mathrm{m}^{2}\right) ;(n)$ & $23 \pm 1.4(6)$ & $32 \pm 1.4^{*}(6)$ & $34 \pm 1.4^{*}(6)$ & $33 \pm 2.4^{*}(6)$ \\
\hline Fasting glucose $(\mathrm{nmol} / \mathrm{l})(n)$ & $4.5 \pm 0.22(6)$ & $5.0 \pm 0.55(6)$ & $5.5 \pm 0.65(6)$ & $9.2 \pm 3.28^{*}(6)$ \\
\hline $\begin{array}{l}\text { 2 h oral glucose tolerance test }(\mathrm{OGTT}) \\
\text { glucose }(\mathrm{nmol} / \mathrm{l})(n)\end{array}$ & $5.08 \pm 1.40(5)$ & $5.31 \pm 1.26^{*}(5)$ & $7.83 \pm 0.9^{* \wedge}(6)$ & $11.3 \pm 2.7^{* \wedge}(3)$ \\
\hline Insulin sensitivity index $(\mathrm{T} ; \mathrm{mg} / \mathrm{kg} / \mathrm{min})(n)$ & $7.9 \pm 1.41(6)$ & $5.1 \pm 1.65^{*}(6)$ & $2.7 \pm 0.42^{* \wedge}(5)$ & $2.2 \pm 0,74^{* \wedge}(5)$ \\
\hline Fasting triglycerides $(\mathrm{nmol} / \mathrm{l})(n)$ & $1.0 \pm 0.47(6)$ & $1.36 \pm 0.49(6)$ & $2.2 \pm 1.07(6)$ & $2.5 \pm 1.12^{*}(6)$ \\
\hline Fasting insulin $(\mu \mathrm{lU} / \mathrm{ml})(n)$ & $8.0 \pm 2.8(3)$ & $9.37 \pm 1.6(3)$ & $15.2 \pm 2.3^{*}(4)$ & $20.1 \pm 2.2^{* \wedge}(6)$ \\
\hline
\end{tabular}

Data are means \pm SEM

NGT - normal glucose tolerance; IGT - impaired glucose tolerance; * $-\mathrm{P}<0.05$ vs control (lean group);

$\wedge-\mathrm{P}<0.05$ vs obese (NGT) group

Результати представлені як $\mathrm{M} \pm \mathrm{m}$

NGT - нормальна толерантність до глюкози; IGT - порушена толерантність до глюкози; * - P < 0,05 порівняно з контролем (група худих); ^ $-\mathrm{P}<0,05$ порівняно з групою з ожирінням (NGT)

RNA isolation. RNasy Lipid Tissue Mini Kit (QIAGEN, Germany) was used for RNA extraction from subcutaneous adipose tissue of lean and obese individuals as well as obese patients with type 2 diabetes and prediabetic traits.

Reverse transcription and quantitative real-time polymerase chain reaction analysis. The expression levels of genes related to regulation of an angiogenesis (TIMP1, TIMP2, TIMP3, TIMP4, THBS1, THBS2, THBS3, ADAMTS5, LUM, DCN, IL6 and ZEB1) were measured in subcutaneous fat tissue by real-time quantitative polymerase chain reaction of complementary DNA (cDNA). QuaniTect Reverse Transcription Kit (QIAGEN, Germany) was used for cDNA synthesis. The 7900 HT Fast Real-Time PCR System (Applied Biosystems), Absolute QPCR SYBRGreen Mix (Thermo Scientific, UK) and pair of primers specific for each studied gene (Sigma, USA) were used for quantitative polymerase chain reaction. Sequences of these primers are shown in Table 2.

The expression of beta-actin mRNA was used as control of analyzed RNA quantity. An analysis of quantitative PCR was performed using special computer program „Differential expression calculator" and statistical analysis - in Excel program. Results are represented as $\%$ of control (lean individuals) and are the means \pm SEM for six different samples.

The amplified DNA fragments were analyzed on a $2 \%$ agarose gel and that visualized by $5 \times$ Sight DNA Stain (EUROMEDEA).

\section{RESULTS}

In this study we have analyzed the expression levels of four genes encoded tissue inhibitor of matrix metalloproteinase (TIMP metallopeptidase inhibitor; TIMP1, TIMP2, TIMP3 and TIMP4), three genes encoded thrombospondin (THBS1, THBS2 and THBS3), ADAM metallopeptidase with thrombospondin type 1 motif, 5 (ADAMTS5), lumican (LUM), decorin (DCN), interleukin 6 (IL6) and transcription factor ZEB1 in adipose tissue from four groups of participants: lean (control), obese with normal glucose tolerance test (NGT), obese with impaired glucose tolerance (IGT; prediabetes) and obese individuals with type 2 diabetes. 
Table 2. Characteristics of the primers used for quantitative real-time polymerase chain reaction

Таблиця 2. Характеристика праймерів, використаних для кількісної полімеразної ланцюгової реакції у реальному часі

\begin{tabular}{|c|c|c|c|}
\hline $\begin{array}{l}\text { Gene } \\
\text { symbol }\end{array}$ & Primer's sequence & $\begin{array}{l}\text { Nucleotide numbers } \\
\text { in sequence }\end{array}$ & $\begin{array}{c}\text { GenBank } \\
\text { accession number } \\
\end{array}$ \\
\hline TIMP1 & $\begin{array}{l}\text { F: 5'-AATTCCGACCTCGTCATCAG } \\
\text { R: 3'-TGCAGTTTTCCAGCAATGAG }\end{array}$ & $\begin{array}{c}301-320 \\
530-511\end{array}$ & NM_003254 \\
\hline TIMP2 & $\begin{array}{l}\text { F: 5'-GATGCACATCACCCTCTGTG } \\
\text { R: 3'-GTCGAGAAACTCCTGCTTGG }\end{array}$ & $\begin{array}{l}665-684 \\
950-931\end{array}$ & NM_003255 \\
\hline TIMP3 & $\begin{array}{l}\text { F: 5'-CTGACAGGTCGCGTCTATGA } \\
\text { R: 3'-GGCGTAGTGTTTGGACTGGT }\end{array}$ & $\begin{array}{l}1496-1515 \\
1735-1716\end{array}$ & NM_000362 \\
\hline TIMP4 & $\begin{array}{l}\text { F: 5'-CAGACCCTGCTGACACTGAA } \\
\text { R: 3'-AGACTTTCCCTCTGCACCAA }\end{array}$ & $\begin{array}{l}696-715 \\
954-935\end{array}$ & NM_003256 \\
\hline THBS1 & $\begin{array}{l}\text { F: 5'-TTCTACGAGCTGTGGCAATG } \\
\text { R: 3'-TTTCTTGCAGGCTTTGGTCT }\end{array}$ & $\begin{array}{l}1352-1371 \\
1637-1618\end{array}$ & NM_003246 \\
\hline THBS2 & $\begin{array}{l}\text { F: 5'-AGCGTCAGATGTGCAACAAG } \\
\text { R: 3'-CTTGTCCTTGCATGGGTTTT }\end{array}$ & $\begin{array}{l}1864-1883 \\
2213-2194\end{array}$ & NM_003247 \\
\hline THBS3 & $\begin{array}{l}\text { F: 5'-GCCTTCAATGGTGTGGACTT } \\
\text { R: 3'-AGTATGCCACAGGGCATTTC }\end{array}$ & $\begin{array}{l}2416-2435 \\
2661-2642\end{array}$ & NM_007112 \\
\hline ADAMTS5 & $\begin{array}{l}\text { F: 5'-GCCTGGAAGTGAGCAAGAAC } \\
\text { R: 3'-TTTCGTGAGCCACAGTGAAG }\end{array}$ & $\begin{array}{l}1709-1728 \\
1963-1944\end{array}$ & NM_007038 \\
\hline LUM & $\begin{array}{l}\text { F: 5'-TGATCTGCAGTGGCTCATTC } \\
\text { R: 3'-AAAAGAGCCCAGCTTTGTGA }\end{array}$ & $\begin{array}{l}659-678 \\
854-835\end{array}$ & NM_002345 \\
\hline$D C N$ & $\begin{array}{l}\text { F: 5'-AATTGAAAATGGGGCTTTCC } \\
\text { R: 3'-GCCATTGTCAACAGCAGAGA }\end{array}$ & $\begin{array}{c}978-997 \\
1197-1178\end{array}$ & NM_001920 \\
\hline IL6 & $\begin{array}{l}\text { F: 5'-AAAGAGGCACTGGCAGAAAA } \\
\text { R: 3'-CAGGGGTGGTTATTGCATCT }\end{array}$ & $\begin{array}{l}360-379 \\
618-599\end{array}$ & NM_000600 \\
\hline ZEB1 & $\begin{array}{l}\text { F: 5'-TGCACTGAGTGTGGAAAAGC } \\
\text { R: 3'-TGGTGATGCTGAAAGAGACG }\end{array}$ & $\begin{array}{c}787-806 \\
1023-1004\end{array}$ & NM_030751 \\
\hline ACTB & $\begin{array}{l}\text { F: 5'-GGACTTCGAGCAAGAGATGG } \\
\text { R: 3'-AGCACTGTGTTGGCGTACAG }\end{array}$ & $\begin{array}{l}747-766 \\
980-961\end{array}$ & NM_001101 \\
\hline
\end{tabular}

As shown in Table 1, obese individuals have significantly higher body mass index (BMI), which is a main criteria of obesity, and lower insulin sensitivity index. In obese patients with impaired glucose tolerance, versus obese subjects with normal glucose tolerance, the $2 \mathrm{~h}$ oral glucose tolerance test (OGTT), fasting triglycerides and fasting insulin levels significantly increased, but decreased insulin sensitivity index (Table 1). This data clearly demonstrated that this group of patients has insulin resistance and impaired glucose tolerance. The group of obese individuals with type 2 diabetes has a significantly higher level of fasting glucose $(9.2 \pm 1.34 \mathrm{mmol} / \mathrm{l})$ and of $2 \mathrm{~h}$ oral glucose tolerance test $(11.3 \pm 1.57 \mathrm{mmol} / \mathrm{l})$ as compared to all other groups of patients as well as fasting insulin and triglycerides level, but decreased insulin sensitivity index as compared to lean or obese patients with normal glucose tolerance (Table 1). Thus, the group of 
obese individuals with type 2 diabetes corresponds to the WHO (1999) criteria as fasting plasma glucose $>7.0 \mathrm{mmol} / \mathrm{l}$ or $2 \mathrm{~h}$ glucose $>11.1 \mathrm{mmol} / \mathrm{l}$ during an OGTT.

As shown in Fig. 1, the expression level of TIMP1 and TIMP2 mRNA in subcutaneous adipose tissue of the obese individuals with normal glucose tolerance significantly increases as compared to the control (lean) subjects: $+56 \%$ and $+183 \%$, correspondingly; however, in obese patients with impaired glucose tolerance (IGT) the expression was higher as compared both to the lean subjects and obese individuals with normal glucose tolerance. At the same time, the expression level of TIMP1 and TIMP2 mRNA in subcutaneous adipose tissue of obese individuals with type 2 diabetes strongly decreases (3.6 and 2.3 fold, correspondingly) as compared to the group of obese subjects with glucose intolerance (Fig. 1).

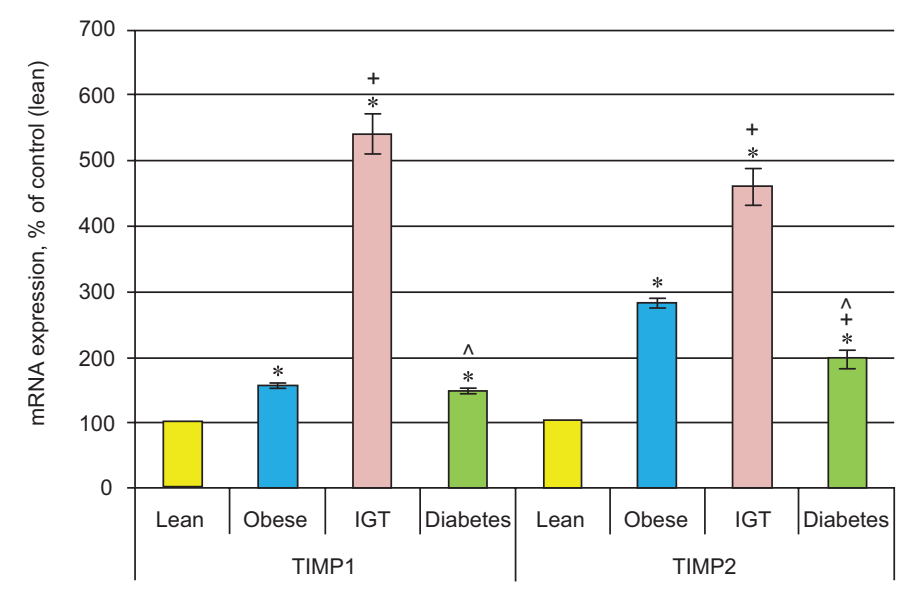

Fig. 1. The expression level of TIMP metallopeptidase inhibitor 1 and 2 (TIMP1 and TIMP2) mRNA in subcutaneous adipose tissue of lean and obese individuals as well as in obese patients with prediabetic traits (IGT) and type 2 diabetes. The values of TIMP1 and TIMP2 mRNA expressions were normalized to the expression of beta-actin mRNA and are represented as a percent of control (Lean, 100\%). Data is expressed as mean \pm SEM of values from each group; ${ }^{*}-\mathrm{P}<0.05$ vs group of lean individuals; $+-\mathrm{P}<0.05$ vs group with obesity and normal glucose tolerance test (NGT); ${ }^{\wedge}-\mathrm{P}<0.05$ vs group with obesity and impaired glucose tolerance test (IGT)

Рис. 1. Рівень експресії мРНК інгібітора металопептидази TIMP 1 та 2 (TIMP1 та TIMP2) у підшкірній жировій тканині худих людей і з ожирінням, а також у пацієнтів з ожирінням та ознаками предіабету (IGT) або діабету 2-го типу. Значення експресії мРНК TIMP1 та TIMP2 нормалізували на експресію мРНК бета-актину і виражали як відсоток від контролю (худі, 100\%). Дані виражали як $\mathrm{M} \pm m$ для кожної групи $(n=6) ;{ }^{*}-\mathrm{P}<0,05$ порівняно з групою худих; + $-\mathrm{P}<0,05$ порівняно з групою, що мали ожиріння та нормальний глюкозо-толерантний тест (NGT); ${ }^{\wedge}-\mathrm{P}<0,05$ порівняно з групою з ожирінням та порушеним глюкозо-толерантним тестом (IGT)

Significantly less changes were observed in the expression level of TIMP3 mRNA in subcutaneous adipose tissue of obese patients with normal glucose tolerance $(+36 \%)$; however, in obese individuals with impaired glucose tolerance the expression of this gene was increased in 2.3 fold as compared to obese individuals with NGT (Fig. 2). At the same time, no significant changes were found in TIMP4 gene expression in adipose tissue of obese individuals both with normal glucose tolerance and type 2 diabetes (Fig. 2).

As shown in Fig. 3, in subcutaneous adipose tissue of obese men with normal glucose tolerance the expression level of genes, which encode for thrombospondin-1 and thrombospondin-2, also increases as compared to lean individuals, being more intense

ISSN 1996-4536 • Біологічні Студії / Studia Biologica • 2012 • Том 6/№2 • С. 17-32 
for THBS2; however, in obese patients with impaired glucose tolerance the expression level of THBS1 gene increases more strongly than THBS2 in comparisson to the group of obese subjects with normal glucose tolerance. At the same time, no significant changes were found in THBS3 gene expression in subcutaneous adipose tissue of obese individuals with normal glucose tolerance versus lean subjects, glucose intolerance; however, leads to an increase of this gene expression (Fig. 4).

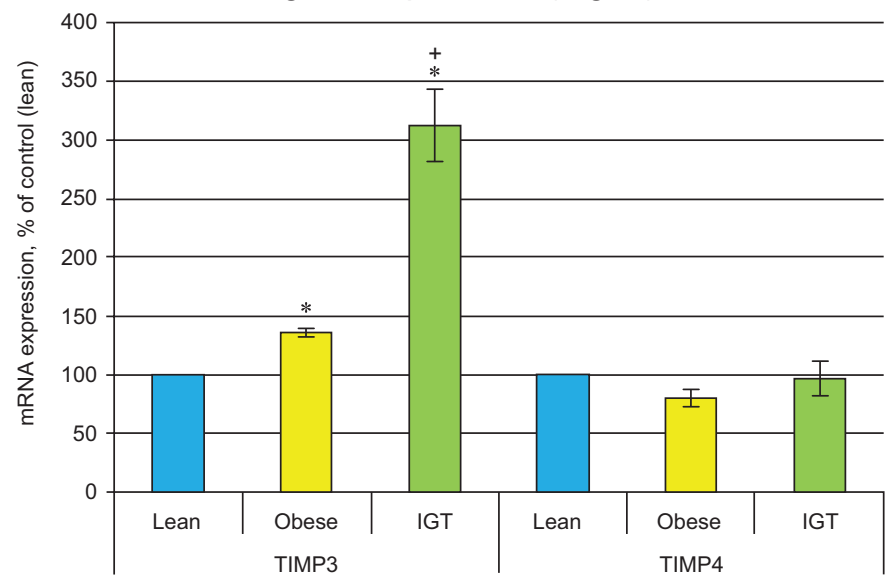

Fig. 2. The expression level of TIMP metallopeptidase inhibitor 3 and 4 (TIMP3 and TIMP4) mRNA in subcutaneous adipose tissue of lean and obese individuals as well as in obese patients with prediabetic traits (IGT). The values of TIMP3 and TIMP4 mRNA expressions were normalized to the expression of beta-actin mRNA and are represented as a percent of control (Lean, 100\%). Data is expressed as mean \pm SEM of values from each group; ${ }^{*}-\mathrm{P}<0.05$ vs group of lean individuals; $+-\mathrm{P}<0.05$ vs group with obesity and normal glucose tolerance test (NGT)

Рис. 2. Рівень експресії мРНК інгібітора металопептидази TIMP 3 та 4 (TIMP3 та TIMP4) у підшкірній жировій тканині худих людей і з ожирінням, а також у пацієнтів з ожирінням та ознаками предіабету (IGT). Значення експресії мPHК TIMP3 та TIMP4 нормалізували на експресію мРНК бета-актину і виражали як відсоток від контролю (худі, 100\%). Дані виражали як $\mathrm{M} \pm m$ для кожної групи $(n=6) ;$ * - P < 0,05 порівняно з групою худих; $+-\mathrm{P}<0,05$ порівняно з групою з ожирінням та нормальним глюкозо-толерантним тестом (NGT)

We have also studied the expression level of the gene, which encodes for ADAMTS5, metallopeptidase with thrombospondin type 1 motif, and have shown that its expression increases in subcutaneous adipose tissue both in the group of obese men with normal glucose tolerance and glucose intolerance: $+21 \%$ and $+82 \%$, correspondingly, as compared to the group of lean individuals (Fig. 4).

As shown in Fig. 5 and 6, obesity leads to an increase of the expression level of genes, encoded the lumican, decorin and interleukin- 6 , in subcutaneous adipose tissue versus lean individuals, being more intense for $L U M$; however, in obese patients with impaired glucose tolerance the expression level of LUM and IL6 genes decreases, as compared to group of obese individuals with normal glucose tolerance. At the same time, glucose intolerance does not significantly change the expression level of DCN mRNA in adipose tissue (Fig. 6). Analysis of the expression of transcription factor ZEB1 which likely plays a role in transcriptional repression showed that obesity inhibits its expression and that this expression level of ZEB1 mRNA does not change significantly in the group of obese individuals both with glucose intolerance and type 2 diabetes mellitus (Fig. 6). 


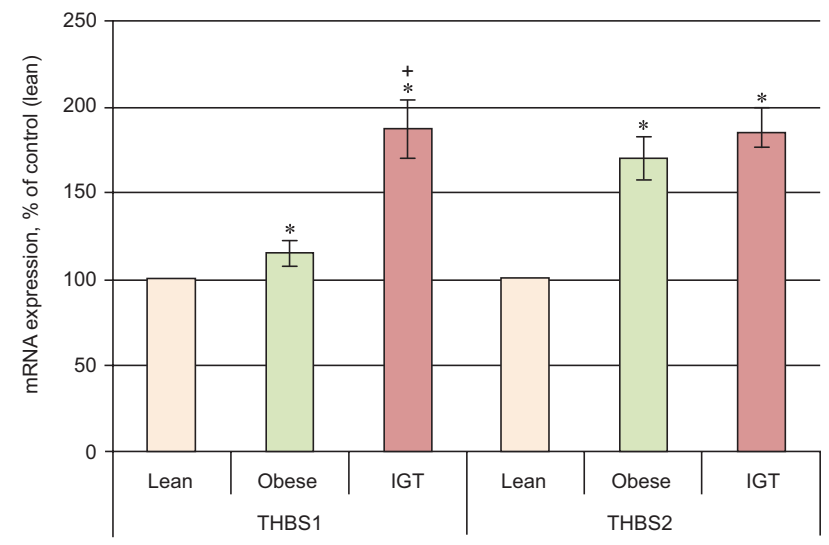

Fig. 3. The expression level of thrombospondin 1 and 2 (THBS1 and THBS2) mRNA in subcutaneous adipose tissue of lean and obese individuals as well as in obese patients with prediabetic traits (IGT) The values of THBS1 and THBS2 mRNA expressions were normalized to the expression of betaactin mRNA and are represented as a percent of control (Lean, 100\%). Data is expressed as mean \pm SEM of values from each group; ${ }^{*}-\mathrm{P}<0.05$ vs group of lean individuals; $+-\mathrm{P}<0.05$ vs group with obesity and normal glucose tolerance test (NGT)

Рис. 3. Рівень експресії мРНК тромбоспондину 1 та 2 (THBS1 та THBS2) у підшкірній жировій тканині худих людей та з ожирінням, а також у пацієнтів з ожирінням та ознаками предіабету (IGT). Значення експресії мРНК THBS1 та THBS2 нормалізували на експресію мРНК бета-актину і виражали як відсоток від контролю (худі, 100\%). Дані виражали як $\mathrm{M} \pm m$ для кожної групи $(n=6) ;{ }^{*}-\mathrm{P}<0,05$ порівняно з групою худих; +толерантним тестом (NGT)

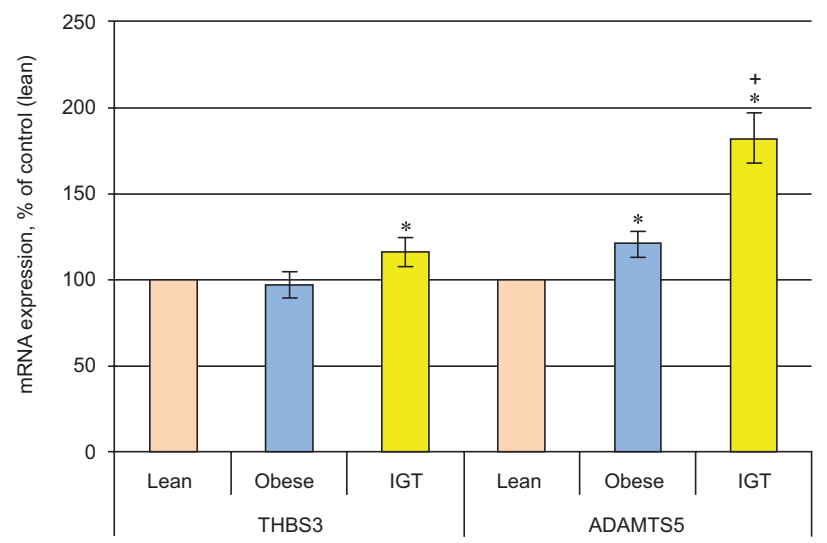

Fig. 4. The expression level of thrombospondin 3 (THBS3) and ADAM metallopeptidase with thrombospondin type 1 motif, 5 (ADAMTS5) mRNA in subcutaneous adipose tissue of lean and obese individuals as well as in obese patients with prediabetic traits (IGT). The values of THBS3 and ADAMTS5 mRNA expressions were normalized to the expression of beta-actin mRNA and are represented as a percent of control (Lean, $100 \%$ ). Data is expressed as mean \pm SEM of values from each group; ${ }^{*}-\mathrm{P}<0.05$ vs group of lean individuals; $+-\mathrm{P}<0.05$ vs group with obesity and normal glucose tolerance test (NGT)

Рис. 4. Рівень експресії мРНК тромбоспондину 3 (THBS3) і ADAM металопептидази 5 з мотивом тромбоспондину типу 1 (ADAMTS5) у підшкірній жировій тканині худих людей та з ожирінням, а також у пацієнтів з ожирінням та ознаками предіабету (IGT). Значення експресії мPHК THBS3 і ADAMTS5 нормалізували на експресію мРНК бета-актину і виражали як відсоток від контролю (худі, 100\%). Дані виражали як $\mathrm{M} \pm m$ для кожної групи $(n=6) ;{ }^{*}-\mathrm{P}<0,05$ порівняно з групою худих; $+-\mathrm{P}<0,05$ порівняно з групою з ожирінням та нормальним глюкозо-толерантним тестом (NGT) 


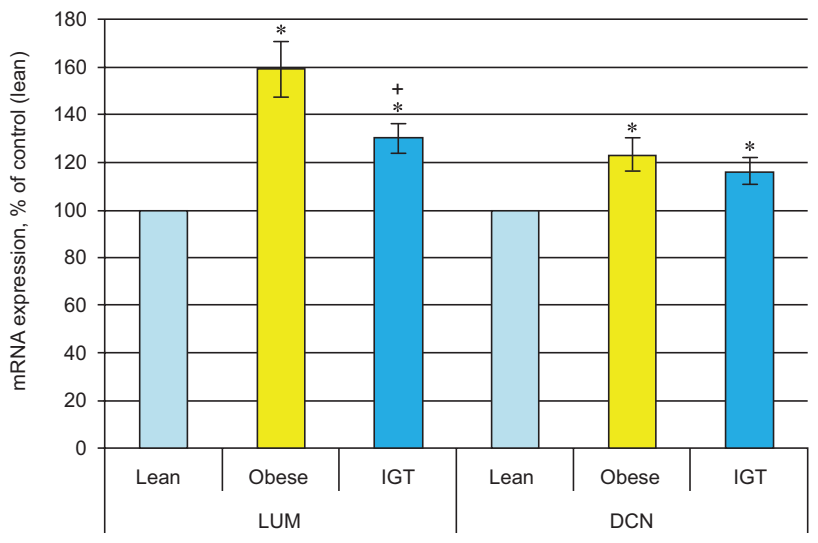

Fig. 5. The expression level of lumican ( $L U M)$ and decorin $(D C N)$ mRNA in subcutaneous adipose tissue of lean and obese individuals as well as in obese patients with prediabetic traits (IGT). The values of LUM and DCN mRNA expressions were normalized to the expression of beta-actin mRNA and are represented as a percent of control (Lean, 100\%). Data is expressed as mean \pm SEM of values from each group; * $-\mathrm{P}<0.05$ vs group of lean individuals; $+-\mathrm{P}<0.05$ vs group with obesity and normal glucose tolerance test (NGT)

Рис. 5. Рівень експресії мРНК люмікану (LUM) та декорину (DCN) у підшкірній жировій тканині худих людей та з ожирінням, а також у пацієнтів з ожирінням та ознаками предіабету (IGT). Значення експресії MPHK LUM та DCN нормалізували на експресію мРНК бета-актину і виражали як відсоток від контролю (худі, 100\%). Дані виражали як $\mathrm{M} \pm m$ для кожної групи $(n=6) ;{ }^{*}-\mathrm{P}<0,05$ порівняно з групою худих; + - P < 0,05 порівняно з групою, що мали ожиріння та нормальний глюкозо-толерантний тест (NGT)

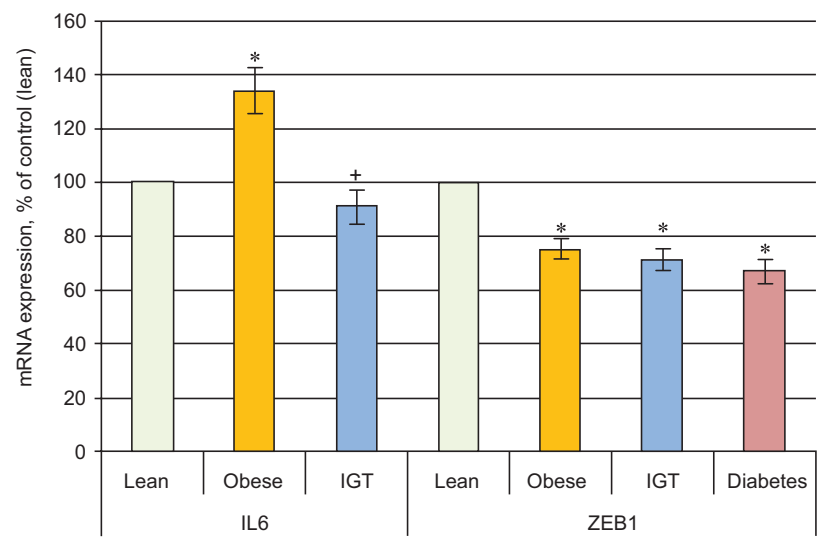

Fig. 6. The expression level of interleukin 6 (IL6) and transcription factor zinc finger E-box binding homeobox 1 (ZEB1) mRNA in subcutaneous adipose tissue of lean and obese individuals as well as in obese patients with prediabetic traits (IGT). The values of IL6 and ZEB1 mRNA expressions were normalized to the expression of beta-actin mRNA and are represented as a percent of control (Lean, 100\%). Data is expressed as mean \pm SEM of values from each group; * $-\mathrm{P}<0.05$ vs group of lean individuals; $+-\mathrm{P}<0.05$ vs group with obesity and normal glucose tolerance test (NGT)

Рис. 6. Рівень експресії мРНК інтерлейкіну 6 (IL6) та транскрипційного фрактора zinc finger E-box binding homeobox 1 (ZEB1) у підшкірній жировій тканині худих людей та з ожирінням, а також у пацієнтів з ожирінням та ознаками предіабету (IGT). Значення експресії мPHK IL6 та ZEB1 нормалізували на експресію мРНК бета-актину і виражали як відсоток від контролю (худі, 100 \%). Дані виражали як $\mathrm{M} \pm m$ для кожної групи $(n=6) ;{ }^{*}-\mathrm{P}<0,05$ порівняно з групою худих; $+-\mathrm{P}<0,05$ порівняно з групою, що мали ожиріння та нормальний глюкозо-толерантний тест (NGT) 


\section{DISCUSSION}

In this study, we have demonstrated that obesity is associated with dysregulation of genes encoded the important regulatory factors which control angiogenesis and growth processes involved in the development of the obesity, metabolic syndrome and type 2 diabetes mellitus, the most profound public health problems. Angiogenesis is an important component of different proliferative processes, in particular, fat tissue growth; however, angiogenesis can also contribute to the development of diabetic complications. We have studied the expression of genes mostly related to suppression of an angiogenesis in subcutaneous adipose tissue of obese individuals as well as obese patients with impaired glucose tolerance and type 2 diabetes mellitus. The results of our investigation have shown that obesity leads to a significant increase of the expression of TIMP1, TIMP2, TIMP3, THBS1, THBS2, ADAMTS5, LUM, DCN and IL6 genes in subcutaneous adipose tissue, besides that, the most significant increase was shown for TIMP1, TIMP2, THBS2 and LUM genes. These findings are largely consistent with data from previous studies about the involvement of these genes in the regulation of different proliferative processes and angiogenesis [7, 15, 16, 18]. Hence, it is possible that these genes are also involved the development of obesity, metabolic syndrome and type 2 diabetes mellitus as well as in the development of diabetic complications and VEGF resistance [8, $13,14,20]$. Putative model linking the dysregulation of circadian clock system with obesity and its complications; glucose intolerance and type 2 diabetes mellitus based on our results is shown in Fig. 7.

It is interesting to note that angiogenesis, like many other biological processes, is regulated by complex network of different factors which are tightly interconnected. Putative scheme of angiogenesis regulation by different factors including TIMP1, TIMP2, TIMP3 and THBS1 as well as pleiotropic functions of TIMP1 and the role of endoplasmic reticulum stress in angiogenesis is shown in Fig. 8. Thus, thrombospondin-1, a matrixbound adhesive glycoprotein, has been shown to modulate tumor progression and upregulates tissue inhibitor of metalloproteinase-1 production in human tumor cells and also up-regulates matrix metalloproteinases MMP-2 and MMP-9 [25]. This data suggested that the balance between matrix metalloproteinases and tissue inhibitors of metalloproteinases is a key determinant in different biological effects of THBS1, including tumor cell invasion, and may provide an explanation for the divergent activities reported for thrombospondin-1 in tumor progression. Thus, the THBS1 is involved in influencing the critical balance between MMPs and their inhibitors, maintaining the controlled degradation of the extracellular matrix needed to support metastasis and possibly in obesity as well as in obesity with impaired glucose tolerance where we find the overexpression of THBS1.

It is possible that ADAMTS5, LUM, DCN, IL6 and ZEB1 are also included in this network and the balance between different regulatory factors which participate in the control of angiogenesis, including vascular endothelial growth factor, a key pro-angiogenic factor, insulin, insulin-like growth factors, leptin and others, really determinate an angiogenesis both in obesity and in obesity with glucose intolerance or type 2 diabetes mellitus. Recently it was shown that the endothelial dysfunction in diabetes associates with vascular endothelial growth factor resistance and disturbed VEGF-related signal transduction pathway despite presence of functionally active VEGF receptor 1 on cell surface from diabetic individuals [52]. Hence, the interpretation of our results of the expression profile of genes, encoded anti-angiogenic factors mostly with pleiotropic func-

ISSN 1996-4536 • Біологічні Студії / Studia Biologica • 2012 • Том 6/№2 • С. 17-32 


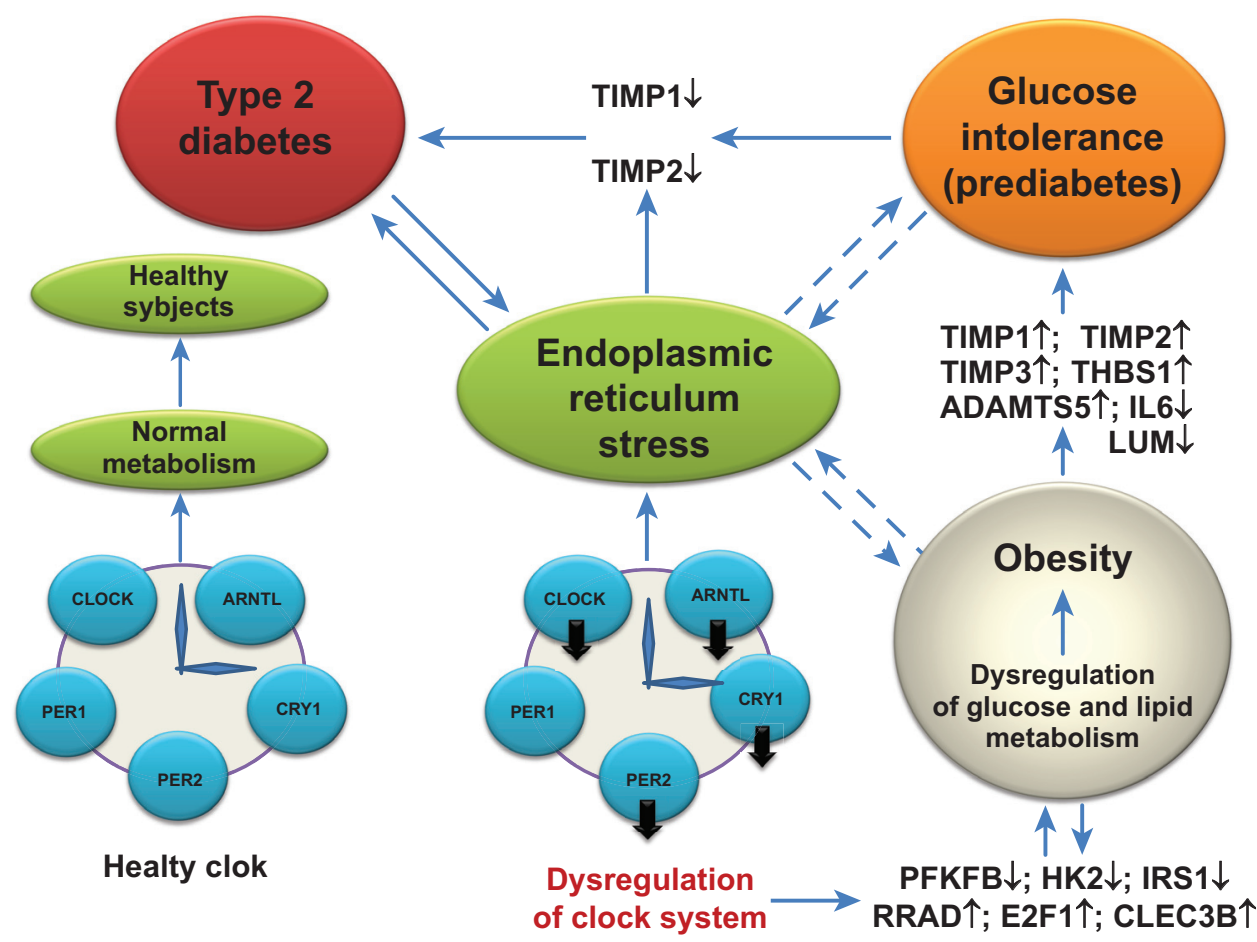

Fig. 7. Putative model linking the dysregulation of the circadian clock system with obesity and its complications; glucose intolerance and type 2 diabetes mellitus based on our results. The expression of key circadian factors CLOCK, ARNTL, PER2 and CRY1, which contribute to regulation of a large array of metabolic pathways, including cellular proliferation, insulin sensitivity, glucose and lipid metabolism, are significantly decreased by environmental and/or genetic factors; as consequence dysregulation of glucose and lipid metabolism by enhancing the expression of TIMP1, TIMP2, TIMP3, THBS1, THBS2 and LUM genes and development of obesity. Obesity with glucose intolerance demonstrated increased expression of TIMP1, TIMP2, TIMP3, THBS1 and ADAMTS5 and decreased expression of IL6 and LUM genes. Most of these genes are responsible for control of angiogenesis. Moreover, development of type 2 diabetes is associated with suppression of TIMP1 and TIMP2 gene expressions. Putative role of endoplasmic reticulum stress in the development of type 2 diabetes by modulating the gene expression is shown. Thus, we identified the changes in gene expressions, which closely related to angiogenesis in obesity and its complication: glucose intolerance and type 2 diabetes

Рис. 7. Гіпотетична модель зв'язків дисрегуляції системи циркадіального годинника за ожиріння та його ускладнень; толерантності до глюкози та діабету 2 типу згідно з нашими результатами. Експресія ключових циркадіальних факторів CLOCK, ARNTL, PER2 та CRY1, які беруть участь у регуляції численних метаболічних шляхів, включаючи проліферацію клітин, чутливість до інсуліну, метаболізм глюкози та ліпідів, суттєво пригнічуються чинниками довкілля та генетичними факторами. Унаслідок цього порушується регуляція метаболізму глюкози та ліпідів шляхом посилення експресії генів TIMP1, TIMP2, TIMP3, THBS1, THBS2 та LUM і розвивається ожиріння. За ожиріння, ускладненого порушеною толерантністю до глюкози, збільшується експресія генів TIMP1, TIMP2, TIMP3, THBS1 та ADAMTS5 і знижується експресія генів IL6 та LUM. Більшість цих генів беруть участь у регуляції ангіогенезу. Більше того, розвиток діабету 2 типу корелює зі суттєвим пригніченням експресії генів TIMP1 та TIMP2. Показана можлива роль стресу ендоплазматичного ретикулуму в розвитку діабету 2 типу шляхом змін в експресії генів. Таким чином, у жировій тканині ми виявили зміни в експресії генів, що належать до регуляторів ангіогенезу, за ожиріння та його ускладнень: порушення толерантності до глюкози та діабету 2 типу 
tion, in subcutaneous adipose tissue of obese individuals with normal glucose tolerance as well as with glucose intolerance and with type 2 diabetes mellitus is a little difficult because obese subjects with complications like glucose intolerance and type 2 diabetes have resistance to insulin, VEGF and possibly to many other important regulatory factors; however, this aspect of the regulatory mechanisms remains unknown yet and warrants further investigation.

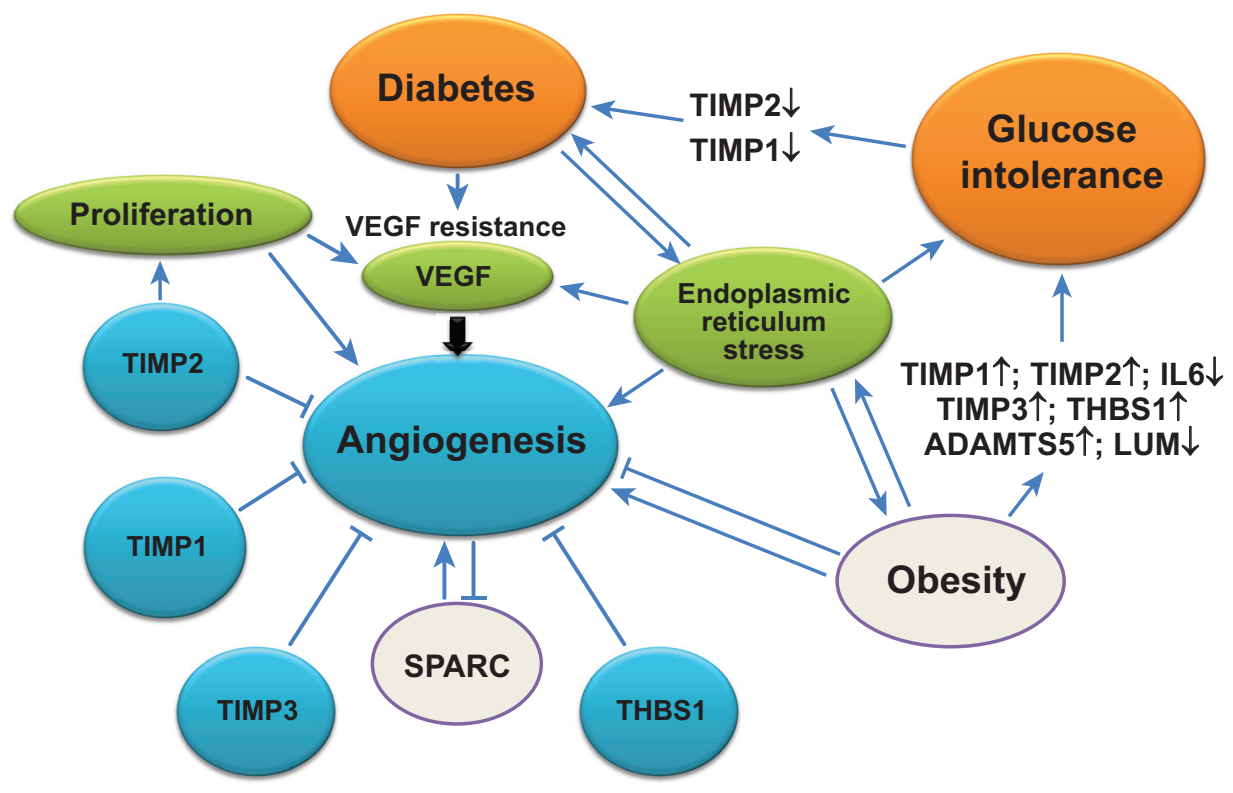

Fig. 8. Putative scheme of angiogenesis regulation by different factors including TIMP1, TIMP2, TIMP3 and THBS1. Pleiotropic functions of TIMP1 and the role of endoplasmic reticulum stress in angiogenesis are shown

Рис. 8. Гіпотетична схема регуляції ангіогенезу різними факторами, включаючи TIMP1, TIMP2, TIMP3 та THBS1. Показані багатогранні функції TIMP1 і роль стресу ендоплазматичного ретикулуму в регуляції ангіогенезу

Endoplasmic reticulum stress is recognized as an important determinant of obesity with type 2 diabetes and contributes to the expression profile of many important regulatory factors resulting in peripheral insulin resistance and diabetic complications, although detailed molecular mechanisms cannot be ruled out. Collectively, these results demonstrate the important role of THBS, TIMP and other regulatory factors with pleiotropic function in developing the obesity and its complications, especially glucose intolerance and insulin resistance.

\section{CONCLUSIONS}

Results of this study provide strong evidence that expression of genes encoded the key regulatory factors with pleiotropic functions, related to the control of proliferation and angiogenesis, in subcutaneous adipose tissue of the obese individuals with normal glucose tolerance as well as in obese patients with glucose intolerance and type 2 diabetes is deregulated. It is possible that these changes in the expression of TIMP and

ISSN 1996-4536 • Біологічні Студії / Studia Biologica • 2012 • Том 6/№2 • С. 17-32 
THBS genes in adipose tissue in obesity as well as in obese individuals with impaired glucose tolerance and type 2 diabetes can contribute to fat tissue storage, insulin and VEGF resistance as well as the development of diabetic complications determined both by insulin resistance and endoplasmic reticulum stress. Collectively, results of this study underscore the crucial role of THBS, TIMP and some other regulatory factors in developing the obesity as well as glucose intolerance, insulin resistance and type 2 diabetes mellitus in obese individuals.

1. Bray M.S., Young M.E. The role of cell-specific circadian clocks in metabolism and disease. Obesity Reviews, 2009; 10(Suppl. 2): 6-13.

2. Bray M.S., Young M.E. Regulation of Fatty Acid Metabolism by Cell Autonomous Circadian Clocks: Time to Fatten up on Information? The Journal of Biological Chemistry, 2011; 286(14): 11883-11889.

3. Turek F.W., Joshu C., Kohsaka A. et al. Obesity and metabolic syndrome in circadian Clock mutant mice. Science, 2005; 308(5724): 1043-1045.

4. Kovac J., Husse J., Oster H. A time to fast, a time to feast: the crosstalk between metabolism and the circadian clock. Molecules and Cells, 2009; 282(2): 75-80.

5. Scott E.M.,Carter A.M.,Grant P.J. Association between polymorphisms in the Clock gene, obesity and the metabolic syndrome in manClock polymorphisms and obesity. International Journal of Obesity, 2008; 32(4): 658-662.

6. Ando H., Kumazaki M., Motosugi Y. et al. Impairment of peripheral circadian clocks precedes metabolic abnormalities in ob/ob mice. Endocrinology, 2011; 152(4): 1347-1354.

7. Takahashi K., Mernaugh R.L., Friedman D.B. et al. Thrombospondin-1 acts as a ligand for CD148 tyrosine phosphatase. The Proceeding of the National Academy of Sciences of the United States of America, 2012; 109(6): 1985-1990.

8. Neill T., Painter H., Buraschi S. et al. Decorin antagonizes the angiogenic network: concurrent inhibition of Met, hypoxia inducible factor 1alpha, vascular endothelial growth factor A, and induction of thrombospondin-1 and TIMP3. The Journal of Biological Chemistry, 2012; 287(8), 5492-5506.

9. Zhao, C.Q., Zhang,Y.H., Jiang,S.D. et al. ADAMTS-5 and intervertebral disc degeneration: the results of tissue immunohistochemistry and in vitro cell culture. Journal of Orthopedy Research, 2011; 29(5): 718-725.

10. MacLauchlan S., Yu J., Parrish M. et al. Endothelial nitric oxide synthase controls the expression of the angiogenesis inhibitor thrombospondin 2. The Proceeding of the National Academy of Sciences of the United States of America, 2011; 108(46): E1137-E1145.

11. Meissburger B., Stachorski L., Roder E. et al. Tissue inhibitor of matrix metalloproteinase 1 (TIMP1) controls adipogenesis in obesity in mice and in humans. Diabetologia, 2011; 54(6): 1468-1479.

12. Dews M., Homayouni A., Yu D. et al. Augmentation of tumor angiogenesis by a Myc-activated microRNA cluster. Nature Genetics, 2006; 38(9):1060-1065.

13. Hashimoto G., Inoki l., Fujii Y. et al. Matrix metalloproteinases cleave connective tissue growth factor and reactivate angiogenic activity of vascular endothelial growth factor 165 . The Journal of Biological Chemistry, 2002; 277(39): 36288-36295.

14. Meissburger B., Ukropec J., Roeder E. et al. Adipogenesis and insulin sensitivity in obesity are regulated by retinoid-related orphan receptor gamma. EMBO Molecular Medicine, 2011; 3(11): 637-651.

15. Hattori N., Carrino D.A., Lauer M.E. et al. Pericellular versican regulates the fibroblast-myofibroblast transition: a role for ADAMTS5 protease-mediated proteolysis. The Journal of Biological Chemistry, 2011; 286(39): 34298-34310. 
16. Bi X., Pohl N.M., Qian Z. et al. Decorin-mediated inhibition of colorectal cancer growth and migration is associated with E-cadherin in vitro and in mice. Carcinogenesis, 2012; 33(2): 326-330.

17. Iozzo R.V., Buraschi S., Genua M. et al. Decorin antagonizes IGF receptor I (IGF-IR) function by interfering with IGF-IR activity and attenuating downstream signaling. The Journal of Biological Chemistry, 2011; 286(40): 34712-34721.

18. Nikitovic D., Chalkiadaki G., Berdiaki A. et al. Lumican regulates osteosarcoma cell adhesion by modulating TGFbeta2 activity. International Journal of Biochemistry and Cell Biology, 2011; 43(6): 928-935.

19. Franklin A.J., Jetton T.L., Shelton K.D., Magnuson M.A. BZP, a novel serum-responsive zinc finger protein that inhibits gene transcription. Molecular and Cellular Biology, 1994; 14(10): 6773-6788.

20. Waltenberger J. VEGF resistance as a molecular basis to explain the angiogenesis paradox in diabetes mellitus. Biochemical Society Transactions, 2009; 37(Pt. 6): 1167-1170.

21. Aragón T., van Anken E., Pincus D. et al. Messenger RNA targeting to endoplasmic reticulum stress signalling sites. Nature, 2009; 457(7230): 736-740.

22. Acosta-Alvear D., Zhou Y., Blais $A$. et al. XBP1 controls diverse cell type- and conditionspecific transcriptional regulatory networks. Molecular Cell, 2007; 27: 53-66.

23. Drogat B., Auguste P., Nguyen D.T. et al. IRE1 signaling is essential for ischemia-induced vascular endothelial growth factor-A expression and contributes to angiogenesis and tumor growth in vivo. Cancer Research, 2007; 67(14): 6700-6707.

24. Lombardi A., Ulianich L., Treglia A.S. et al. Increased hexosamine biosynthetic pathway flux dedifferentiates INS-1E cells and murine islets by an extracellular signal-regulated kinase (ERK)1/2-mediated signal transmission pathway. Diabetologia, 2012; 55(1): 141-153.

25. John A.S., Hu X., Rothman V.L., Tuszynski G.P. Thrombospondin-1 (TSP-1) up-regulates tissue inhibitor of metalloproteinase-1 (TIMP-1) production in human tumor cells: exploring the functional significance in tumor cell invasion. Experimental and Molecular Pathology, 2009; 87(3):184-188.

\title{
ЕКСПРЕСІЯ АНТИ-АНГІОГЕННИХ ГЕНІВ У ПІДШКІРНІЙ ЖИРОВІЙ ТКАНИНІ У ЛЮДЕЙ 3 ОЖИРІННЯМ І ПРЕДІАБЕТОМ АБО ДІАБЕТОМ 2 ТИПУ
}

\author{
О. О. Ратушна 1 , Д. О. Мінченко ${ }^{1,2}$, \\ С. В. Даніловський ${ }^{1}$, І. Клімеші , О. Г. Мінченко \\ ${ }^{1}$ /нститут біохімії ім. О. В. Палладіна НАН України, вул. Леонтовича, 9, Київ 01601, Україна \\ ${ }^{2}$ Національний медичний університет ім. О. О. Богомольця, \\ бульв. Шевченка, 13, Київ 01601, Україна \\ 3/нститут експериментальної ендокринології Словацької академії наук, вул. Влар- \\ ська, 3, Братислава 83306, Словацька Республіка \\ e-mail: ominchenko@yahoo.com
}

Наявні дані підтримують гіпотезу, згідно з якою дисрегуляція різних внутрішніх механізмів, що контролюють більшість метаболічних процесів, задіяні у розвитку ожиріння, метаболічного синдрому та цукрового діабету 2 типу, що є найбільш важливими проблемами охорони здоров'я. Ангіогенез $є$ важливим компонентом різних проліферативних процесів, зокрема росту жирової тканини. Більше того, дисрегуляція молекулярних компонентів системи ангіогенезу може вносити свій вклад у розвиток діабетичних ускладнень. Ми вивчали рівень експресії генів, що мають відношення до регуляції ангіогенезу (TIMP1, TIMP2, TIMP3, TIMP4, THBS1, THBS2,

ISSN 1996-4536 • Біологічні Студії / Studia Biologica • 2012 • Том 6/№2 • С. 17-32 
THBS3, ADAMTS5, LUM, DCN, IL6 та ZEB1) у підшкірній жировій тканині людей з ожирінням, а також пацієнтів з ожирінням і порушеною толерантністю до глюкози (предіабетом) і діабетом 2 типу, використовуючи кількісну ПЛР у реальному часі. Ми показали, що рівень експресії більшості із цих генів з анти-ангіогенними властивостями значно збільшується у підшкірній жировій тканині людей з ожирінням, порівняно з худими пацієнтами, але більш виражені зміни були показані для генів TIMP1, TIMP2, THBS2 та LUM. Збільшений рівень експресії TIMP1, TIMP2, TIMP3, ADAMTS5, THBS1 та THBS2 був виявлений у жировій тканині людей з ожирінням, що мали порушену толерантність до глюкози. У той же час експресія генів, що кодують TIMP1 та TIMP2, сильно зменшується у жировій тканині людей з ожирінням, ускладненим діабетом 2 типу, порівняно з чоловіками, що мали порушену толерантність до глюкози. Результати цього дослідження чітко показують, що регуляція експресії генів, які здебільшого пригнічують ангіогенез, є порушеною у жировій тканині людей з ожирінням, як і у пацієнтів з ожирінням, ускладненим порушеною толерантністю до глюкози або діабетом 2 типу. Можливо, виявлені зміни в експресії генів TIMP and THBS у жировій тканині людей за ожиріння, як і у людей з ожирінням, ускладненим порушеною толерантністю до глюкози або діабетом 2 типу, можуть вносити свій вклад у зберігання жирової тканини, резистентність до інсуліну та розвиток діабетичних ускладнень.

Ключові слова: експресія мРНК, TIMP1, TIMP2, TIMP3, THBS1, THBS2, ADAMTS5, LUM, DCN, ZEB1, жирова тканина людини, ожиріння.

\title{
ЭКСПРЕССИЯ АНТИ-АНГИОГЕННЫХ ГЕНОВ В ПОДКОЖНОЙ ЖИРОВОЙ ТКАНИ У ЛЮДЕЙ С ОЖИРЕНИЕМ И ПРЕДИАБЕТОМ ИЛИ ДИАБЕТОМ 2 ТИПА
}

\author{
О. О. Ратушна ${ }^{1}$, Д. А. Минченко ${ }^{1,2}$ \\ С. В. Даниловский' И. Климеші ${ }^{1}$ А. Г. Минченко \\ ${ }^{1}$ Институт биохимии им. А.В. Палладина НАН Украины \\ ул. Леонтовича, 9, Киев 01601, Украина \\ ${ }^{2}$ Национальный медицинский университет им. А. А. Богомольца, \\ бульв. Шевченко, 13, Киев 01601, Украина \\ ${ }^{3}$ Институт экспериментальной эндокринологии Словацкой академии наук \\ ул. Вларска, 3, Братислава 83306, Словацкая Республика \\ e-mail: ominchenko@yahoo.com
}

Имеющиеся данные поддерживают гипотезу, согласно которой дисрегуляция различных внутренних механизмов, которые контролируют большинство метаболических процессов, задействованы в развитии ожирения, метаболического синдрома и сахарного диабета 2 типа, которые являются наиболее важными проблемами здравоохранения. Ангиогенез является важным компонентом различных пролиферативных процессов, в частности роста жировой ткани. Более того, дисрегуляция молекулярных компонентов системы ангиогенеза может вносить свой вклад в развитие диабетических осложнений. Мы изучали уровень экспрессии генов, имеющих отношение к регуляции ангиогенеза (TIMP1, TIMP2, TIMP3, TIMP4, 
THBS1, THBS2, THBS3, ADAMTS5, LUM, DCN, IL6 и ZEB1), в подкожной жировой ткани людей с ожирением, а также пациентов с ожирением и нарушенной толерантностью к глюкозе (предиабетом) и диабетом 2 типа, используя количественный ПЦР в реальном времени. Мы показали, что уровень экспрессии большинства из этих генов с анти-ангиогенными свойствами значительно увеличивается в подкожной жировой ткани людей с ожирением, по сравнению с худыми пациентами, но более выраженные изменения были показаны для генов TIMP1, TIMP2, THBS2 и LUM. Увеличенный уровень экспрессии TIMP1, TIMP2, TIMP3, ADAMTS5, THBS1 и THBS2 был выявлен в жировой ткани людей с ожирением, которые имели нарушенную толерантность к глюкозе. В то же время экспрессия генов, которые кодируют TIMP1 и TIMP2, сильно уменьшается в жировой ткани людей с ожирением, усложненным диабетом 2 типа, в сравнении с мужчинами, которые имели нарушенную толерантность к глюкозе. Результаты этого исследования четко доказывают, что регуляция экспрессии генов, которые в большинстве случаев угнетают ангиогенез, является нарушенной в жировой ткани людей с ожирением, как и у пациентов с ожирением, осложненным нарушенной толерантностью к глюкозе или диабетом 2 типа. Возможно, что выявленные изменения в экспрессии генов TIMP и THBS в жировой ткани людей с ожирением, как и у людей с ожирением, осложненным нарушенной толерантностью к глюкозе или диабетом 2 типа, могут вносить свой вклад в сохранение жировой ткани, резистентность к инсулину и развитие диабетических осложнений.

Ключевые слова: экспрессия МРHК, TIMP1, TIMP2, TIMP3, THBS1, THBS2, ADAMTS5, LUM, DCN, ZEB1, жировая ткань человека, ожирение.

Одержано: 16.07.2012

ISSN 1996-4536 • Біологічні Студії / Studia Biologica • 2012 • Том 6/№2 • С. 17-32 